\title{
PENGARUH KEPEMIMPINAN DAN LINGKUNGAN KERJA TERHADAP KEPUASAN KERJA PADA PT. POS INDONESIA KANTOR CABANG CINERE
}

\author{
${ }^{1 *}$ Muhamad Saddam, ${ }^{2}$ Ridwan Faroji, ${ }^{3}$ Najibullah, ${ }^{4}$ Nur Imam Duta Waskita \\ 1.2.3 Sekolah Tinggi Iimu Ekonomi Hidayatullah, Depok, Jawa Barat, Indonesia \\ ${ }^{4}$ Sekolah Tinggi limu Ekonomi GICI Business School, Kota Bogor, Jawa Barat, Indonesia \\ *muhammad.saddam@stiehidayatullah.ac.id
}

\begin{abstract}
Abstrak
Penelitian ini bertujuan untuk mengetahui pengaruh kepemimpinan dan lingkungan kerja terhadap kepuasan kerja pada PT. POS Indonesia Kantor Cabang Cinere. Metode yang digunakan adalah explanatory research dengan teknik analisis menggunakan analisis statistik dengan pengujian regresi, korelasi, determinasi dan uji hipotesis. Hasil penelitian ini kepemimpinan berpengaruh signifikan terhadap kepuasan kerja sebesar $45,3 \%$, uji hipotesis diperoleh $\mathrm{t}$ hitung $>\mathrm{t}$ tabel atau $(9,001>1,984)$. Lingkungan kerja berpengaruh signifikan terhadap kepuasan kerja sebesar $44,2 \%$, uji hipotesis diperoleh $t$ hitung $>t$ tabel atau $(8,806>1,984)$. Kepemimpinan dan lingkungan kerja secara simultan berpengaruh signifikan terhadap kepuasan kerja dengan persamaan regresi $Y=10,553+0,365 X 1+$ $0,378 \times 2$. Kontribusi pengaruh sebesar $53,6 \%$, uji hipotesis diperoleh $\mathrm{F}$ hitung $>\mathrm{F}$ tabel atau $(56,081>2,700)$.
\end{abstract}

Kata Kunci: Kepemimpinan, Lingkungan kerja, Kepuasan kerja.

This study aims to determine the effect of leadership and work environment on job satisfaction at PT. POS Indonesia Cinere Branch Office. The method used is explanatory research with analytical techniques using statistical analysis with regression, correlation, determination and hypothesis testing. The results of this study that leadership has a significant effect on job satisfaction by $45.3 \%$, hypothesis testing is obtained $t$ count $>t$ table or $(9,001>1,984)$. The work environment has a significant effect on job satisfaction by $44.2 \%$, hypothesis testing is obtained $t$ count $>t$ table or $(8.806>1.984)$. Leadership and work environment simultaneously have a significant effect on job satisfaction with the regression equation $Y=10,553+0.365 X 1+0.378 X 2$. The influence contribution is $53.6 \%$, the hypothesis test is obtained by F arithmetic $>$ F table or $(56.081>2.700)$. Keywords: Leadership, work environment, job satisfaction. 


\section{PENDAHULUAN}

Ruang lingkup manajemen sumberdaya manusia secara umum membahas hal-hal berkaitan dengan manusiawi termasuk di dalamnya adalah kepuasan kerja pegawai.Kepuasan kerja pegawai merupakan faktor yangdianggap penting, karena dapat mempengaruhi jalannya organisasi secara keseluruhan.Kepuasan yang dirasakan pegawai dalam bekerja merupakansuatu petunjuk bahwa pegawai memilikiperasaan senang dalam menjalankantugas pekerjaan.Kepuasan kerja juga merupakan suatu sikap positif pegawai terhadap berbagai situasi di tempat pekerjaan.Bagi organisasi, kepuasan kerja pegawai harus mendapat perhatian dan pemenuhan hal ini terutama menjadi tugas pimpinan organisasi.Bagi karyawan, kepuasan kerja merupakan faktor individu dan sarana untuk mencapai produktivitas kerja. Jadi dalam lingkup manajemen sumber daya manusia, faktor kepuasan kerja memberikan manfaat baik bagi organisasi/perusahaan, pegawai,bahkan bagi masyarakat.Kepuasan kerja merupakan sikap umum seorang individu terhadap pekerjaannya,seorang dengan tingkat kepuasan kerja tinggi menunjukkan sikap yang positif terhadap pekerjaan itu, seorang yang tidak puas dengan pekerjaannya menunjukkan sikap negatif terhadap pekerjaan itu (Robbins,2001:139).

Kepuasan kerja bagi seorang pegawai merupakan faktor yang amat penting karena kepuasan yang diperolehnya akan turut menentukan sikap positif terhadap pekerjaan. Perasaan puas dalam bekerja dapat menimbulkan dampak positif terhadap perilaku, seperti misalnya tingkat kedisiplinan dan semangat kerja yang cenderung meningkat. Kepuasan kerja juga berhubungan dengan outcomes seperti kinerja, sehingga apabila kepuasan kerja semakin tinggi maka akan menimbulkan semangat dalam bekerja. Dengan demikian seseorang akan lebih mudah mencapai tingginya kinerja.

Penelitian Tiffin (Mukhyi dan Sunarni, 2007) menyatakan bahwa kepuasan kerja berhubungan erat dengan sikap seseorang terhadap pekerjaannya sendiri, karena makin tinggi tingkat kepuasan kerja seseorang akan tercermin dari sikap kerja ke arahyang positif. Hal ini tidak berarti apayang dilakukan oleh pegawai yang ada pada saat ini arahnya negatif. Sebaliknya ketidakpuasan kerja akan menimbulkan sikap kerja yang negatif.Positif dan negatifnya sikap kerja seseorang mengikuti tingkat kepuasan kerjayang dirasakan.

Penelitian Tiffin (Mukhyi dan Sunarni, 2007) menyatakan bahwa kepuasan kerja berhubungan erat dengan sikap seseorang terhadap pekerjaannya sendiri, karena makin tinggi tingkat kepuasan kerja seseorang akan tercermin dari sikap kerja ke arahyang positif. Hal ini tidak berarti apayang dilakukan oleh pegawai yang ada pada saat ini arahnya negatif. Sebaliknya ketidakpuasan kerja akan menimbulkan sikap kerja yang negatif.Positif dan negatifnya sikap kerja seseorang mengikuti tingkat kepuasan kerjayang dirasakan.

Kepuasan kerja sebagai dependent variabel dinyatakan dipengaruhi secara positif oleh lingkungan kerja.Kepuasan kerja selain dipengaruhi oleh lingkungan kerja, juga dipengaruhi oleh kepemimpinan.Penelitian yang dilakukan Kelner (Satria, 2005) menunjukkan bahwa kepuasan kerjaselain dipengaruhi oleh lingkungan kerja, juga dipengaruhi oleh kepemimpinan. Lingkungan yangbaik dan hubungan kerjayang baik dapat meningkatkan kepuasan kerja karyawan, karena kepemimpinan yang baik merupakan salah satufaktor yang menunjang semangat dan motivasi kerjakaryawan, tentu saja bersama dengan komitmen organisasi yang ada dalam diri karyawan.

Untuk meningkatkan kepuasan kerja karyawan, perlu adanya lingkungan kerja yang baik.Menurut Suad Husnan (2002: 187), "Lingkungan kerja merupakan suatu bentuk pelayanan perusahaan terhadap karyawan agar menunjang kinerja dalam memenuhi kebutuhan karyawan, sehingga 
dapat meningkatkan produktifitas kerja karyawan".

Adanya lingkungan kerja yang disediakan oleh PT. POS Indonesia Kantor Cabang Cinere sangat mendukung karyawan dalam bekerja. Lingkungan kerja tersebut sebagai alat atau sarana dan prasarana untuk membantu karyawan agar lebih mudah menyelesaikan pekerjaannya dan karyawan akan bekerja lebih produktif. Menurut jurnal dengan adanya lingkungan kerja karyawan akan merasa nyaman dalam bekerja dan menimbulkan semangat kerja untuk mendapatkan hasil yang diharapkan oleh perusahaan. Variabel lingkungan kerja dapat dilihat dari adanya lingkungan pendukung seperti: Lingkungan ruang ber AC, ibadah, toilet / WC dan lain-lain.

Kegiatan manusia secara bersamasama selalu membutuhkan kepemimpinan. Jadi harus ada pemimpin demi sukses dan efisiensi kerja. Untuk macam-macam usaha dari kegiatan manusia yang jutaan banyaknya ini diperlukan upaya yang terencana dan sistematis untuk melatih dan mempersiapkan pemimpin-pemimpin baru.

Kepemimpinan diartikan sebagai perilaku atau cara yang dipilih dan dipergunakan pemimpin dalam mempengaruhi pikiran, perasaan, sikap dan perilaku para anggota atau bawahannya (Nawawi, 2003: 113). Kepemimpinan merupakan norma perilaku orang lain, atau dapat pula dikatakan bahwa kepemimpinan adalah suatu pola perilaku yang konsisten ditunjukkan sebagainya yang diketahui oleh pihak lain ketika seorang pemimpin berusaha mempengaruhi kegiatan-kegiatan orang lain. Seorang pemimpin mempunyai kapasitas untuk membaca situasi yang dihadapinya dan menyesuaikan kepemimpinannya sesuai dengan situasi tersebut, meskipun penyesuaian ini hanya bersifat sementara. Setiap pemimpin mempunyai sifat, kebiasaan, watak dan kepribadian sendiri yang unik/khas, sehingga tingkah laku dan gayanya membedakan dari pemimpin yang lain.
Tugas seorang pemimpin dalam mewujutkan kepuasan kerja pegawai, hal lain yang ikut mempengaruhinya adalah lingkungan kerja. Tanpa adanya lingkungan yang memadai, maka peran pegawai akan merasa jenuh dan kurang bergairah dalam melaksanakan tugasnya. Hal ini disebabkan oleh adanya rasa ketidakpuasan dari pegawai itu sendiri terhadap pekerjaannya. Jadi dengan kata lain, untuk dapat memberikan rasa puas bagi pegawai terhadap pekerjaannya adalah dengan adanya lingkungan yang memadai.

Kelengkapan sarana dan lingkungan kerja akan mendorong timbulnya hasil kerja yang efektif, efisien serta mendorong peningkatan kualitas, yang seiring dengan standar kerja yang ada. Lingkungan kerja yang disediakan perusahaan haruslah disesuaikan dengan kebutuhan perusahaan, sehingga pekerjaan yang dikerjakan oleh karyawan dapat berjalan dengan efektif (Hasibuan, 2007: 183).

Lingkungan kerja dan Kepemimpinan merupakan salah satu faktor yang dapat mempengaruhi kepuasan kerja bagi setiap karyawan, semakin baik kepemimpinan dan lingkungan maka semakin tinggi tingkat kepuasan kerja karyawan, begitu juga sebaliknya semakin buruk dan tidak efektifnya kepemimpinan dan lingkungan akan mempengaruhi kepuasan kerja karyawan. Hal demikian dapat dilihat dengan tingginya tingkat absensi karyawan.

\section{TINJAUAN PUSTAKA}

\section{Kepemimpinan}

Setiap pemimpin memiliki karakteristik tertentu yang timbul pada situasi yang berbeda. Kepemimpinan yang sesuai dengan keadaan perusahaan dan keinginan karyawan akan mendorong peningkatan kinerja karyawan dalam pencapaian sasaran dan tujuan perusahaan dalam pelaksanaan kegiatannya para pemimpin mempunyai cara tersendiri untuk mempengaruhi dan mengarahkan karyawannya. Menurut Handoko 
(2019:294) berpendapat bahwa “Kepemimpinan merupakan kemampuan yang dipunyai seseorang untuk memepengaruhi orang-orang lain agar bekerja mencapai tujuan dan sasaran"

\section{Lingkungan kerja}

Lingkungan kerja adalah keseluruhan sarana prasarana kerja yang ada disekitar karyawan yang sedang melaksanakan pekerjaan yang dapat mempengaruhi pekerjaan itu sendiri, lingkungan kerja didesain sedemikian rupa agar dapat tercipta hubungan kerja yang mengikat pekerja dengan lingkungan. Lingkungan kerja adalah keseluruhan alat perkakas dan bahan yang dihadapi, lingkungan sekitarnya dimana seseorang bekerja, metode kerjanya serta pengaturan kerjanya baik sebagai perseorangan maupun kelompok. Sedarmayanti (2020:21)

\section{Kepuasan kerja}

Sebuah perusahaan didalam perkembangannya sangat tergantung bagaimana karyawan yang ada didalamnya. Kepuasan kerja pegawai menyangkut perasaan positif pegawai dalam menjalankan pekerjaannya. Dengan terciptanya dengan baik dan juga pegawai dapat merasakan kepuasan yang secara tidak langsung akan mendorong pegawainya berprestasi dengan baik. Menurut Badeni (2019:43) mengemukakan bahwa "Kepuasan kerja karyawan adalah sikap seseorang terhadap pekerjaannya yang dapat berupa sikap positif atau negatif, puas atau tidak puas".

\section{Model Penelitian}

Menurut pendapat Sugiyono (2018) "Model penelitian merupakan sintesa yang mencerminkan keterkaitan antara variabel yang diteliti dan merupakan tuntunan untuk memecahkan masalah penelitian serta merumuskan hipotesis yang berbentuk bagan alur yang dilengkapi penjelasan kualitatif". Dalam penelitian ini model penelitian yang dibuat sebagai berikut:

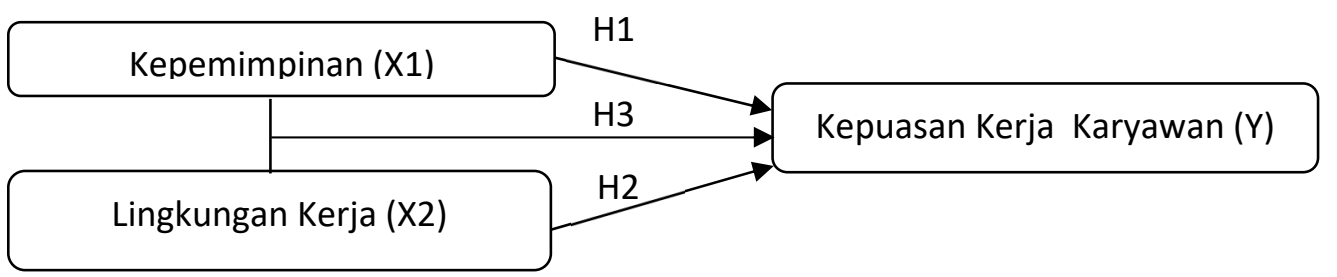

\section{Hipotesis Penelitian}

Menurut Sugiyono (2018:63) berpendapat "hipotesis merupakan jawaban sementara terhadap rumusan masalah penelitian, dimana rumusan masalah dinyatakan dalam kalimat pernyataan". Dengan demikian, hipotesis yang peneliti ajukan adalah sebagai berikut:

$\mathrm{H} 1$ :Diduga terdapat pengaruh yang signifikan kepemimpinan terhadap kepuasan kerja pada PT. POS Indonesia Kantor Cabang Cinere .

$\mathrm{H} 2$ :Diduga terdapat pengaruh yang signifikan lingkungan kerja terhadap kepuasan kerja pada PT. POS Indonesia Kantor Cabang Cinere .
H3 :Diduga terdapat pengaruh yang signifikan kepemimpinan dan lingkungan kerja secara simultan terhadap kepuasan kerja pada PT. POS Indonesia Kantor Cabang Cinere .

\section{METODE PENELITIAN}

\section{Jenis Penelitian}

Jenis penelitian ini adalah kuantitatif, menurut Sugiyono (2018:8) penelitian kuantitatif adalah: "Metode penelitian yang berlandaskan pada filsafat positivisme, digunakan untuk meneliti pada populasi atau sampel tertentu, pengumpulan data menggunakan instrument penelitian, analisis data bersifat kuantutatif atau 
statistik, dengan tujuan untuk menguji hipotesis yang telah ditetapkan". Adapun pendekatan dalam penelitian ini digunakan deskriptif dan verivikatif.

\section{Populasi}

Populasi merupakan sekumpulan objek yang ditentukan melalui suatu kriteria tertentu yang akan dikategorikan ke dalam objek yang akan diteliti. Menurut Sugiyono (2018) mendefinisikan "populasi adalah jumlah wilayah generalisasi yang terdiri atas obyek atau subyek yang mempunyai kualitas dan karakteristik yang ditetapkan oleh peneliti dan kemudian ditarik kesimpulannya". Adapun populasi dalam penelitian berjumlah 100 responden PT. POS Indonesia Kantor Cabang Cinere

3. Sampel

Menurut Sugiyono (2018) yaitu "Sampel adalah jumlah dan karakteristik yang dimiliki oleh populasi tersebut". Sedangkan Suharsini Arikunto (2010) berpendapat bahwa "Sampel adalah sebagian atau wakil populasi yang diteliti". Teknik pengambilan sampling dalam penelitian ini adalah samplel jenuh, dimana semua anggota populasi dijadikan sebagai sampel. Dengan demikian sampel dalam penelitian ini berjumlah 100 responden.

\section{Jenis Penelitian}

Jenis penelitian yang dipakai adalah kuantitatif, dimana tujuannya adalah untuk mengetahui mencari keterhubungan antara variabel independen terhadap variabel dependen.

\section{Teknik Analisis Data}

Dalam menganalisis data digunakan uji instrumen, uji asumsi klasik, regresi, koefisien korelasi, koefisien determinasi dan uji hipotesis.

\section{a. Uji Instrumen}

Pada pengujian ini digunakan uji validitas dan uji reliabilitas.

1) Uji Validitas.

Uji validitas dimaksudkan untuk mengetahui ketepatan data tentang kesesuaian antara yang mau diukur dengan hasil pengukurannya. Menurut Sugiyono (2018) "Valid berarti terdapat kesamaan antara data yang terkumpul dengan data yang sesungguhnya". Untuk melakukan uji validitas dilihat nilai signifikansi 2 tailed dibandingkan dengan 0,05 dengan dengan ketentuan:

(a) Jika nilai signifikansi 2 talied < 0,05, maka instrumen valid,

(b) Jika nilai signifikansi 2 talied > 0,05, maka instrumen tidak valid,

2) Uji Reliabilitas.

Uji reliabilitas merupakan serangkaian pengukuran atau serangkaian alat ukur yang memiliki konsistensi bila pengukuran yang dilakukan dengan alat ukur itu dilakukan secara berulang. Instrumen yang baik tidak akan bersifat tendensius mengarahkan responden untuk memilih jawaban tertentu. Menurut Sugiyono (2018:168) berpendapat "instrumen yang reliabel jika digunakan beberapa kali untuk mengukur obyek yang sama, akan menghasilkan data yang sama. Adapun kriteria yang digunakan sebagai berikut:

(a) Jika Cronbach's Alpha >0,600, maka instrumen reliabel.

(b) Jika Cronbach's Alpha < 0,600, maka instrumen tidak reliabel.

\section{b. Uji Asumsi Klasik}

Uji asumsi klasik dimaksudkan untuk mengetahui ketepatan sebuah data. Menurut Singgih Santoso (2015) "Sebuah model regresi akan digunakan untuk melakukan peramalan, sebuah model yang baik adalah model dengan kesalahan peramalan yang seminimal mungkin". Karena itu, sebuah model sebelum digunakan seharusnya memenuhi beberapa asumsi, yang biasa disebut asumsi klasik. Dalam 
penelitian ini uji asumsi klasik yang digunakan adalah meliputi: Uji Normalitas, Uji Multikolinearitas, Uji Autokorelasi, dan Uji Heterokedastisitas. Adapun hasilnya sebagai berikut:

1) Uji Normalitas

Uji normalitas digunakan untuk menguji apakah dalam sebuah model regresi, variabel dependen, variabel independen, atau keduanya mempunyai distribusi normal atau tidak. Menurut Ghozali (2017:160) berpendapat "model regresi yang baik adalah berdistribusi normal atau mendekati normal". Uji normilitas menggunakan Kolmogorov-Smirnov test, dengan ketentuan:

(a) Jika nilai signifikansi $<0,05$, maka data tidak berdistribusi normal.

(b) Jika nilai signifikansi $>0,05$, maka data berdistribusi normal.

2) Uji Multikolinieritas

Uji Multikolinieritas ini bertujuan menguji apakah pada model regresi ditemukan adanya korelasi antar variabel independen. Menurut Ghozali (2017:105), “uji multikolineritas bertujuan untuk menguji apakah pada model regresi ditemukan adanya korelasi antar variabel bebas (independen)". Dalam penelitian ini digunakan batas tolerance dan lawannya, variance inflation factor (VIF) dengan ketentuan:

(a) Jika nilai nilai tolerance lebih $<1$ dan nilai Variance Inflation Factor (VIF) < dari 1, maka tidak terjadi multikolinieritas.

(b) Jika nilai nilai tolerance lebih $>1$ dan nilai Variance Inflation Factor $(\mathrm{VIF})>$ dari 1, maka terjadi multikolinieritas.

3) Uji Autokorelasi

Uji autokorelasi digunakan untuk mengetahui ada atau tidaknya penyimpangan asumsi klasik autokorelasi, yaitu adanya korelasi antar anggota sampel. Menurut Ghozali (2017:110) berpendapat bahwa "uji autokorelasi bertujuan menguji apakah dalam model regresi liner ada korelasi antar kesalahan pengganggu pada periode $t$ dengan kesalahan pengganggu pada periode $t-1$ ". Dalam penelitian ini digunakan Durbin Watson Test.

4) Uji Heterskedastisitas Menurut Ghozali (2017:139) berpendapat "uji heteroskedastisitas bertujuan untuk mengetahui apakah dalam model regresi terjadi ketidaksamaan varian dari suatu residual pengamatan ke pengamatan lain". Cara menprediksi ada atau tidaknya heteroskedastisitas digunakan Glejser Test.

\section{c. Uji Statistik}

1) Regresi Linier

Analisis regresi liner merupakan suatu teknik statistika yang digunakan untuk mencari persamaan regresi yang bermanfaat untuk meramal nilai variabel dependen berdasarkan nilai-nilai variabel independen. Menurut Sugiyono (2018:277) "analisis regresi digunakan untuk melakukan prediksi bagaimana perubahan nilai variabel dependen bila nilai variabel independen dinaikan/diturunkan". Dalam penelitian ini digunakan regresi linier berganda.

2) Koefisien Korelasi

Menurut Sugiyono (2018:274) berpendapat "analisis koefisien korelasi dimaksudkan untuk mengetahui tingkat kekuatan hubungan antara variabel independen dengan 
variabel dependen baik secara parsial maupun simultan".

3) Koefisien Determinasi Analisis koefisien determinasi dimaksudkan untuk mengetahui besarnya pengaruh antara variabel independen terhadap variabel dependen baik secara parsial maupun simultan. Menurut Andi Supangat (2015:350) berpendapat "koefisien determinasi merupakan besaran untuk menunjukkan tingkat kekuatan hubungan antara dua variabel atau lebih dalam bentuk persen"

4) Uji Hipotesis

Pengujian hipotesis dimaksudkan untuk menentukan apakah suatu hipotesis sebaiknya diterima atau ditolak. Menurut Sugiyono (2018:213) berpendapat "hipotesis merupakan jawaban sementara terhadap rumusan masalah penelitian, oleh karena itu rumusan masalah penelitian biasanya disusun dalam bentuk kalimat pertanyaan." Dalam penelitian ini digunakan uji $t$ (Parsial) dan uji F (Simultan).

\section{PENUTUP}

\section{Uji Intrumen}

(a) Dari hasil pengujian diperoleh seluruh item kuesioner variabel kepemimpinan diperoleh nilai signifikansi 2 tailed sebesar 0,000 < 0,05 , dengan demikian instrumen valid.

(b)Dari hasil pengujian diperoleh seluruh item kuesioner variabel lingkungan kerja diperoleh nilai signifikansi 2 tailed sebesar 0,000 < 0,05 , dengan demikian instrumen valid.

(c) Dari hasil pengujian diperoleh seluruh item kuesioner variabel kepuasan kerja diperoleh nilai signifikansi 2 tailed sebesar $0,000<$ 0,05 , dengan demikian instrumen valid.

(d)Dari hasil pengujian reliabilitas, diperoleh hasil sebagai berikut:

Tabel 1. Hasil Pengujian Reliabilitas

\begin{tabular}{|l|c|c|c|}
\hline \multicolumn{1}{|c|}{ Variabel } & Cronbach's Alpha & Standar Kritis Alpha & Keterangan \\
\hline Kepemimpinan $(\mathrm{X} 1)$ & 0,642 & 0,600 & Reliabel \\
\hline Lingkungan kerja $(\mathrm{X} 2)$ & 0,644 & 0,600 & Reliabel \\
\hline Kepuasan kerja $(\mathrm{Y})$ & 0,643 & 0,600 & Reliabel \\
\hline
\end{tabular}

Berdasarkan hasil pengujuan di atas, keseluruhan variabel kepemimpinan (X1), lingkungan kerja (X2) diperoleh nilai cronbach alpha lebih besar dari 0,600. Dengan demikian dinyatakan reliabel.
2. Uji Asumsi Klasik

a. Uji Normalitas

Hasil uji normalitas dengan alat uji Kolmogorov-Smirnov Test, sebagai berikut:

Tabel 2. Hasil Normalitas Kolmogorov-Smirnov Test

Tests of Normality

\begin{tabular}{l|l} 
Kolmogorov-Smirnova & Shapiro-Wilk
\end{tabular}

\begin{tabular}{lr|c|r|r|r|r} 
& \multicolumn{3}{c|}{ Kolmogorov-Smirnov } & \multicolumn{3}{c}{ Shapiro-Wilk } \\
& Statistic & df & Sig. & Statistic & df & Sig. \\
\hline Kepuasan kerja $(\mathrm{Y})$ & .083 & 100 & .083 & .974 & 100 & .045 \\
\hline
\end{tabular}

*. This is a lower bound of the true significance.

a. Lilliefors Significance Correction

Berdasarkan hasil pengujian pada tabel diatas diperoleh nilai signifikansi 0,083 dimana nilai tersebut lebih besar dari nilai $\alpha=0,050$ atau $(0,083>0,050)$. Dengan demikian maka asumsi distribusi persamaan pada uji ini adalah normal. 
b. Uji Multikonilieritas

Uji multikolinearitas dilakukan dengan melihat nilai Tolerance Value dan

Tabel 3. Hasil Uji Multikolinieritas dengan Collinierity Statistic.

Coefficients ${ }^{\mathrm{a}}$

\begin{tabular}{|c|c|c|c|c|c|}
\hline \multirow[b]{3}{*}{ Model } & \multicolumn{3}{|c|}{ Coefficients ${ }^{a}$} & \multirow{2}{*}{\multicolumn{2}{|c|}{$\begin{array}{c}\text { Collinearity } \\
\text { Statistics }\end{array}$}} \\
\hline & \multicolumn{2}{|c|}{$\begin{array}{l}\text { Unstandardized } \\
\text { Coefficients }\end{array}$} & \multirow{2}{*}{$\begin{array}{c}\text { Standardized } \\
\text { Coefficients } \\
\text { Beta }\end{array}$} & & \\
\hline & B & Std. Error & & Tolerance & VIF \\
\hline 1 (Constant) & 10.553 & 2.701 & & & \\
\hline Kepemimpinan (X1) & .365 & .082 & .413 & .554 & 1.806 \\
\hline Lingkungan kerja (X2) & .378 & .090 & .389 & .554 & 1.806 \\
\hline
\end{tabular}

a. Dependent Variable: Kepuasan kerja $(\mathrm{Y})$

Berdasarkan hasil pengujian pada tabel diatas nilai tolerance masing-masing variabel bebas yaitu $0,554<1,0$ dan nilai Variance Inflation Factor (VIF) sebesar $1,806<10$, dengan demikian model regresi ini tidak terjadi multikolinearitas.

Variance Inflation Factor (VIF). Adapun hasil pengujiannya sebagai berikut:

\section{c. Uji Autokorelasi}

Pengujian dilakukan dengan alat uji Darbin-Watson (DW test). Adapun hasil pengujiannya sebagai berikut:

Tabel 4. Hasil Uji Autokorelasi

Model Summary

\begin{tabular}{ll|l|l|l|l|} 
Model & $\mathrm{R}$ & $\mathrm{R}$ Square & Adjusted R Square & Std. Error of the Estimate & Durbin-Watson \\
\hline 1
\end{tabular}

\begin{tabular}{lrrrrr}
\hline 1 & $.732^{\mathrm{a}}$ & .536 & .527 & 2.463 & 2.087 \\
\hline
\end{tabular}

a. Predictors: (Constant), Lingkungan kerja (X2), Kepemimpinan (X1)

b. Dependent Variable: Kepuasan kerja $(\mathrm{Y})$

Hasil pengujian pada tabel diatas diperoleh nilai Durbin-Watson sebesar 2,087 nilai tersebut berada diantara interval 1.550 - 2.460. Dengan demikian model regresi dinyatakan tidak ada gangguan autokorelasi.

Tabel 5. Hasil Uji Heteroskesdastisitas dengan Glejser Test Model

\section{Coefficients ${ }^{a}$}

Unstandardized Coefficients Standardized Coefficients

\begin{tabular}{lr|r|r|r|r} 
Model & $\mathrm{B}$ & Std. Error & Beta & \multicolumn{1}{c}{$\mathrm{t}$} & Sig. \\
\hline 1 (Constant) & 2.125 & 1.573 & & 1.351 & .180 \\
\hline Kepemimpinan $(\mathrm{X} 1)$ & -.075 & .048 & -.212 & -1.572 & .119 \\
\hline Lingkungan kerja $(\mathrm{X} 2)$ & .070 & .053 & .179 & 1.331 & .186 \\
\hline
\end{tabular}

a. Dependent Variable: RES2

Hasil pengujian dengan menggunakan uji glejser diperoleh nilai Sig. > 0,05. Dengan demikian regression model tidak ada gangguan heteroskesdastisitas.

\section{Analisis Deskriptif}

Pada pengujian ini digunakan untuk mengetahui skor minimum dan maksimum, mean score dan standar deviasi dari masing-masing variabel. Adapun hasilnya sebagai berikut:

Tabel 6. Hasil Analisis Descriptive Statistics

Descriptive Statistics

$\mathrm{N}$ Minimum Maximum Mean Std. Deviation

\begin{tabular}{l|l|l|l|l|l|}
\hline Kepemimpinan (X1) & 100 & 31 & 48 & 37.84 & 4.054 \\
\hline Lingkungan kerja (X2) & 100 & 27 & 46 & 38.20 & 3.682 \\
\hline
\end{tabular}




\begin{tabular}{l|l|l|l|l|l}
\hline Kepuasan kerja (Y) & 100 & 32 & 46 & 38.79 & 3.580 \\
\hline Valid N (listwise) & 100 & & & & \\
\hline
\end{tabular}

Kepemimpinan diperoleh varians minimum sebesar 31 dan varians maximum 48 dengan mean score sebesar 3,784dengan standar deviasi 4,054.

Lingkungan kerja diperoleh varians minimum sebesar 27 dan varians maximum 46 dengan mean score sebesar 3,828 dengan standar deviasi 3,682.

Kepuasan kerja diperoleh varians minimum sebesar 32 dan varians maximum 46 dengan mean score sebesar
3,879 dengan standar deviasi 3,580.

\section{Analisis Kuantitatif}

Pada analisis ini dimaksudkan untuk mengetahui pengaruh variabel independen terhadap variabel dependen. Adapun hasil pengujian sebagai berikut:

\section{a. Analisis Regresi Linier Berganda}

Hasil Pengujian regresi linier berganda sebagai berikut:

Tabel 7. Hasil Pengujian Regresi Linier Berganda

\section{Coefficients ${ }^{\mathrm{a}}$}

Unstandardized Coefficients Standardized Coefficients

\begin{tabular}{lr|r|r|r|r} 
Model & B & Std. Error & Beta & t & Sig. \\
\hline 1 (Constant) & 10.553 & 2.701 & & 3.907 & .000 \\
\hline Kepemimpinan $(\mathrm{X} 1)$ & .365 & .082 & .413 & 4.446 & .000 \\
\hline Lingkungan kerja $(\mathrm{X} 2)$ & .378 & .090 & .389 & 4.183 & .000 \\
\hline
\end{tabular}

Berdasarkan hasil pengujian pada tabel di atas, diperoleh persamaan regresi $\mathrm{Y}=10,553+$ 0,365X1 + 0,378X2. Dari persamaan tersebut dijelaskan sebagai berikut:

1) Konstanta sebesar 10,553 diartikan jika kepemimpinan dan lingkungan kerja tidak ada, maka telah terdapat nilai kepuasan kerja sebesar 10,553 point.

2) Koefisien regresi kepemimpinan sebesar 0,365, angka ini positif artinya setiap ada peningkatan kepemimpinan sebesar 0,365 maka Tabel 8. Hasil Pengujian Koefisien Korelasi Kepemimpinan Terhadap Kepuasan kerja. Correlations $^{\mathrm{b}}$

\begin{tabular}{llr|r} 
& & Kepemimpinan (X1) & Kepuasan kerja (Y) \\
\hline Kepemimpinan (X1) & Pearson Correlation & 1 & $.673^{* *}$ \\
\cline { 2 - 4 } & Sig. (2-tailed) & & .000 \\
\hline Kepuasan kerja (Y) & Pearson Correlation & $.673^{* *}$ & 1 \\
\cline { 2 - 4 } & Sig. (2-tailed) & .000 & \\
\hline
\end{tabular}

Berdasarkan hasil pengujian diperoleh nilai korelasi sebesar 0,673 artinya kepemimpinan memiliki kepuasan kerja juga akan mengalami peningkatan sebesar 0,365 point.

3) Koefisien regresi lingkungan kerja sebesar 0,378, angka ini positif artinya setiap ada peningkatan lingkungan kerja sebesar 0,378 maka kepuasan kerja juga akan mengalami peningkatan sebesar 0,378 point.

\section{b. Analisis Koefisien Korelasi}

Hasil pengujian koefisien korelasi sebagai berikut: 
Tabel 9. Hasil Pengujian Koefisien Korelasi Lingkungan kerja Terhadap Kepuasan kerja.

Correlations $^{b}$

\begin{tabular}{llr|r} 
& & \multicolumn{3}{c}{ Lingkungan kerja (X2) } & Kepuasan kerja (Y) \\
\hline Lingkungan kerja (X2) & Pearson Correlation & 1 & $.665^{\text {** }}$ \\
\cline { 2 - 4 } & Sig. (2-tailed) & .000 \\
\hline Kepuasan kerja (Y) & Pearson Correlation & $.065^{\star *}$ & 1 \\
\cline { 2 - 4 } & Sig. (2-tailed) & .000 & \\
\hline
\end{tabular}

Berdasarkan hasil pengujian diperoleh nilai korelasi sebesar 0,665 artinya lingkungan kerja memiliki hubungan yang kuat terhadap kepuasan kerja.

Tabel 10. Hasil Pengujian Koefisien Korelasi Kepemimpinan dan Lingkungan kerja secara simultan Terhadap Kepuasan kerja.

\section{Model Summary}

\begin{tabular}{lr|r|r|r} 
Model & $\mathrm{R}$ & $\mathrm{R}$ Square & Adjusted R Square & Std. Error of the Estimate \\
\hline 1 & $.732^{\mathrm{a}}$ & .536 & .527 & 2.463 \\
\hline a. Predictors: (Constant), Lingkungan kerja (X2), Kepemimpinan (X1)
\end{tabular}

Berdasarkan hasil pengujian diperoleh nilai korelasi sebesar 0,732 artinya kepemimpinan dan lingkungan kerja secara simultan memiliki hubungan yang kuat terhadap kepuasan kerja.

\section{c. Analisis Koefisien Determinasi}

Hasil pengujian koefisien determinasi sebagai berikut:

Tabel 11. Hasil Pengujian Koefisien Determinasi Kepemimpinan Terhadap Kepuasan kerja.

Model Summary

\begin{tabular}{ll|l|l|l|} 
Model R & R Square & Adjusted R Square & Std. Error of the Estimate \\
\hline 1 &
\end{tabular}

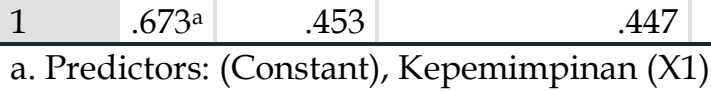

Berdasarkan hasil pengujian

kontribusi pengaruh sebesar $45,3 \%$ diperoleh nilai determinasi sebesar 0,453 artinya kepemimpinan memiliki terhadap kepuasan kerja.

Tabel 12. Hasil Pengujian Koefisien Determinasi Lingkungan kerja Terhadap Kepuasan kerja.

Model Summary

\begin{tabular}{lr|r|r|r} 
Model & R & R Square & Adjusted R Square & Std. Error of the Estimate \\
\hline 1 & $.665^{\mathrm{a}}$ & .442 & .436 & 2.688 \\
\hline
\end{tabular}

a. Predictors: (Constant), Lingkungan kerja (X2)

Berdasarkan hasil pengujian memiliki kontribusi pengaruh sebesar diperoleh nilai determinasi sebesar 0,442 artinya lingkungan kerja $44,2 \%$ terhadap kepuasan kerja.

Tabel 13. Hasil Pengujian Koefisien Determinasi Kepemimpinan dan Lingkungan kerja Terhadap Kepuasan kerja.

Model Summary

\begin{tabular}{lr|r|r|r} 
Model & R & R Square & Adjusted R Square & Std. Error of the Estimate \\
\hline 1 & $.732^{\mathrm{a}}$ & .536 & .527 & 2.463 \\
\hline
\end{tabular}

Berdasarkan hasil pengujian

diperoleh nilai determinasi sebesar 
0,536 artinya kepemimpinan dan lingkungan kerja secara simultan memiliki kontribusi pengaruh sebesar $53,6 \%$ terhadap kepuasan kerja, sedangkan sisanya sebesar $46,4 \%$ dipengaruhi faktor lain.

\section{d. Uji Hipotesis}

Uji hipotesis Parsial (Uji t)

Pengujian hipotesis dengan uji $t$

Tabel 14. Hasil Uji Hipotesis Kepemimpinan Terhadap Kepuasan kerja.

\section{Coefficients}

Unstandardized Coefficients Standardized Coefficients

\begin{tabular}{|c|c|c|c|c|c|}
\hline Model & B & Std. Error & Beta & $\mathrm{t}$ & Sig. \\
\hline 1 (Constant) & 16.314 & 2.511 & & 6.497 & .000 \\
\hline Kepemimpinan (X1) & .594 & .066 & .673 & 9.001 & .000 \\
\hline
\end{tabular}

a. Dependent Variable: Kepuasan kerja (Y)

Berdasarkan hasil pengujian pada tabel di atas, diperoleh nilai $\mathrm{t}$ hitung $>\mathrm{t}$ tabel atau $(9,001>1,984)$, dengan demikian hipotesis pertama

Tabel 15. Hasil Uji Hipotesis Lingkungan kerja Terhadap Kepuasan kerja.

Coefficients $^{\mathrm{a}}$

Unstandardized Coefficients Standardized Coefficients

\begin{tabular}{|c|c|c|c|c|c|}
\hline Model & B & Std. Error & Beta & $\mathrm{t}$ & Sig. \\
\hline 1 (Constant) & 14.105 & 2.816 & & 5.009 & .000 \\
\hline Lingkungan kerja $(\mathrm{X} 2)$ & .646 & .073 & 665 & 8.806 & .000 \\
\hline
\end{tabular}

a. Dependent Variable: Kepuasan kerja $(\mathrm{Y})$
Berdasarkan hasil pengujian pada tabel di atas, diperoleh nilai $\mathrm{t}$ hitung $>\mathrm{t}$ tabel atau $(8,806>1,984)$, dengan demikian hipotesis kedua yang diajukan bahwa terdapat pengaruh yang signifikan atara lingkungan kerja terhadap kepuasan kerja diterima. yang diajukan bahwa terdapat pengaruh yang signifikan atara kepemimpinan terhadap kepuasan kerja diterima. digunakan untuk mengetahui pengaruh yang signifikan kepemimpinan terhadap kepuasan kerja.

pengaruh yang signifikan lingkungan kerja terhadap kepuasan kerja. 
PEMBAHASAN HASIL PENELITIAN

1. Pengaruh Kepemimpinan Terhadap Kepuasan kerja

Dari hasil analisis diperoleh variabel kepemimpinan berpengaruh signifikan terhadap kepuasan kerja dengan nilai korelasi sebesar 0,673 artinya kedua variabel memiliki hubungan yang kuat dengan kontribusi pengaruh sebesar $45,3 \%$. Pengujian hipotesis diperoleh nilai thitung $>\mathrm{t}$ tabel atau $(9,001>1,984)$. Dengan demikian hipotesis pertama yang diajukan bahwa terdapat berpengaruh signifikan antara kepemimpinan terhadap kepuasan kerja diterima.

\section{Pengaruh Lingkungan kerja Terhadap Kepuasan kerja}

Dari hasil analisis diperoleh variabel lingkungan kerja berpengaruh signifikan terhadap kepuasan kerja dengan nilai korelasi sebesar 0,665 artinya kedua variabel memiliki hubungan yang kuat dengan kontribusi pengaruh sebesar $44,2 \%$. Pengujian hipotesis diperoleh nilai $\mathrm{t}$ hitung $>\mathrm{t}$ tabel atau $(8,806>1,984)$. Dengan demikian hipotesis kedua yang diajukan bahwa terdapat berpengaruh signifikan antara lingkungan kerja terhadap kepuasan kerja diterima.

\section{Pengaruh Kepemimpinan dan Lingkungan kerja Terhadap Kepuasan kerja}

Dari hasil analisis diperoleh variabel kepemimpinan dan lingkungan kerja berpengaruh signifikan terhadap kepuasan kerja dengan diperoleh persamaan regresi $Y=10,553+0,365 X 1+$ $0,378 X 2$, nilai korelasi sebesar 0,732 artinya kedua variabel memiliki hubungan yang kuat dengan kontribusi pengaruh sebesar 53,6\% sedangkan sisanya sebesar $46,4 \%$ dipengaruhi faktor lain. Pengujian hipotesis diperoleh nilai $\mathrm{F}$ hitung > F tabel atau $(56,081>2,700)$. Dengan demikian hipotesis ketiga yang diajukan bahwa terdapat berpengaruh signifikan antara kepemimpinan dan lingkungan kerja terhadap kepuasan kerja diterima.

\section{PENUTUP}

\section{Kesimpulan}

a. Kepemimpinan berpengaruh signifikan terhadap kepuasan kerja nilai korelasi sebesar 0,673 atau kuat dengan kontribusi pengaruh sebesar $45,3 \%$. Uji hipotesis diperoleh nilai thitung $>\mathrm{t}$ tabel atau $(9,001>1,984)$. Dengan demikian terdapat pengaruh yang signifikan antara kepemimpinan terhadap kepuasan kerja pada PT. POS Indonesia Kantor Cabang Cinere .

b. Lingkungan kerja berpengaruh signifikan terhadap kepuasan kerja dengan nilai korelasi sebesar 0,665 atau kuat dengan kontribusi pengaruh sebesar $44,2 \%$. Uji hipotesis diperoleh nilai thitung $>\mathrm{t}$ tabel atau $(8,806>1,984)$. Dengan demikian terdapat pengaruh yang signifikan antara lingkungan kerja terhadap kepuasan kerja pada PT. POS Indonesia Kantor Cabang Cinere .

c. Kepemimpinan dan lingkungan kerja berpengaruh signifikan terhadap kepuasan kerja dengan nilai korelasi sebesar 0,732 atau kuat dengan kontribusi pengaruh sebesar 53,6\% sedangkan sisanya sebesar $46,4 \%$ dipengaruhi faktor lain. Uji hipotesis diperoleh nilai $\mathrm{F}$ hitung $>\mathrm{F}$ tabel atau $(56,081>2,700)$. Dengan demikian terdapat pengaruh yang signifikan antara kepemimpinan dan lingkungan kerja secara simultan terhadap kepuasan kerja pada PT. POS Indonesia Kantor Cabang Cinere .

\section{Saran}

a. Dalam cara memimpin karyawan atau bawahannya pimpinan hendaknya mampu memberikan suri tauladan yang baik, dapat terkait dalam cara dan menyelesaikan pekerjaan, tingkah laku mapunun perilaku diluar lingkungan pekerjaan.

b. Perusahaan harus selalu memberikan semangat dan apresiasi yang layak untuk memastikan karyawan memiliki 
semangat kerja yang tinggi.

c. Dalam menumbuhkan kepuasan dalam bekerja, karyawan memerlukan pengakuan dan apresiasi atas pencapaian pekerjaannya. Oleh karenanya perusahaan harus selalu memberikan informasi atas hasil kinerja secara lebih obyektif.

\section{DAFTAR PUSTAKA}

Arikunto, Suharsimi (2014). "Prosedur Penelitian Suatu Pendekatan Praktek". Jakarta: Rineka Cipta.

Edi Sutrisno (2016). Manajemen Sumber Daya Manusia. Jakarta: Prenadamedia Group.

Gerry Dessler (2016) Human Resources Management, Prenticehall, London: International Inc.

Griffin R.W., \& Ronald, J.E. (2003). DasarDasar Pemasaran. Jakarta: Raja

Handoko (2016) Manajemen Personalia dan Sumberdaya Manusia. Yogyakarta: BPFE.

Hasibuan (2016) "Manajemen Sumber Daya Manusia". Haji Masagung. Jakarta.

Henry Simamora (2005), Manajemen Sumber Daya Manusia, STIE YKPN Bandung.

Insani, P. B. E. B. (2020). Hubungan Gaya Kepemimpinan Dengan Produktivitas Kerja Pegawai Bmt El Bina Insani Cugenang. Jurnal Agrita Vol, 2(1).

Kartini Kartono (2011) Pemimpin dan Kepemimpinan, Jakarta: PT. Rajawaligrafindo Persada.

Kristianti, L. S., Affandi, A., Nurjaya, N., Sunarsi, D., \& Rozi, A. (2021). Pengaruh Motivasi Dan Disiplin Kerja Terhadap Kinerja Pegawai Pada Dinas Pariwisata Purwakarta. Jurnal Ilmiah PERKUSI, 1(1), 101-109.

Mangkunegara, Prabu Anwar. (2016). Evaluasi Kinerja SDM. Cetakan ke tujuh, PT Refika Aditama: Bandung.

Nitisemito, Alek.S, (2010), Manajemen Personalia, Ghalia Indonesia, Jakarta.

Muslimat, A., Muhsin, H., Wahid, H. A., Yulistiana, I., Sunarsi, D., Dewi, K., ... \& Ilham, D. (2021). Develop Technology Based Multimedia For
Indonesian Teachers. Journal of Contemporary Issues in Business and Government, 27(1), 1871-1882.

Purwanti, Y. (2021). The Influence Of Digital Marketing \& Innovasion On The School Performance. Turkish Journal of Computer and Mathematics Education (TURCOMAT), 12(7), 118127.

Muslimat, A. (2021). Masa Depan Kampus Merdeka \& Merdeka Belajar: Sebuah Bunga Rampai Dosen. Bintang Visitama Publisher.

Nurjaya, N., Affandi, A., Ilham, D., Jasmani, J., \& Sunarsi, D. (2021). Pengaruh Kompetensi Sumber Daya Manusia Dan Kemampuan Pemanfaatan Teknologi Terhadap Kinerja Aparatur Desa Pada Kantor Kepala Desa Di Kabupaten Gunungkidul, Yogyakarta. JENIUS (Jurnal Ilmiah Manajemen Sumber Daya Manusia), 4(3), 332-346.

Nurjaya, N., Affandi, A., Erlangga, H., Sunarsi, D., \& Jasmani, J. (2021). The Effect of Product Promotion and Innovation Activities on Marketing Performance in Middle Small Micro Enterprises in Cianjur. Budapest International Research and Critics Institute (BIRCI-Journal): Humanities and Social Sciences, 4(1), 528-540.

Paramarta, V., Dewi, R. R. V. K., Rahmanita, F., Hidayati, S., \& Sunarsi, D. (2021). Halal Tourism in Indonesia: Regional Regulation and Indonesian Ulama Council Perspective. International Journal of Criminology and Sociology, 10, 497-505.

Philip Kotler (2017) Manajemen Pemasaran, Edisi Keempat Belas, Jakarta: PT. Indeks.

Prasada, D., Sunarsi, D., \& Teriyan, A. (2020). Pengaruh Etos Kerja Dan Kompensasi Terhadap Komitmen Organisasi Pada DHL Logistic Di Jakarta. JENIUS (Jurnal Ilmiah Manajemen Sumber Daya Manusia), $4(1), 51-60$.

Rivai Veithzal (2015) Manajemen Sumber Daya Manusia Untuk Perusahaan. 
Jakarta: PT Raja Grafindo Persada.

Sedarmayanti (2016) Manajemen Sumber

Daya Manusia, Reformasi Birokrasi dan

Manajemen Karyawan Negeri Sipil,

Cetakan Kelima, Bandung: PT Refika Aditama.

Sugiyono (2017), “Metode Penelitian

Administrasi : dilengkapi dengan
Metode $R \mathcal{E} D^{\prime \prime}$. Bandung: Alfabeta.

Sunarsi, D. (2017). Pengaruh Kepemimpinan Dan Budaya Organisasi terhadap Kinerja Karyawan Pada Cabang Pembantu Bank DKI Pondok Labu-Jakarta Selatan. JENIUS, 1(2), 21. 